\title{
Cross-National Partisan Effects on Agenda Stability
}

Shaun Bevan and Zachary Greene

\begin{abstract}
Studies of policy attention find only mixed support for a partisan impact, instead showing that policy attention reacts more to world events. Yet, a rigorous examination of the ways in which change in the partisan composition of government matters for the distribution of policies across issues has yet to be completed in a cross-national framework. Combining data on policy output from the Comparative Agendas Project, we present a detailed investigation of parties' effect on agenda stability in six advanced industrial democracies over time. We consider parties as dynamic organizations by arguing that parties' organizational characteristics and goals interact with their electoral context to determine their impact on policy attention. The results show that parties' influence on the policy agenda depends on economic conditions, the type of government, the government's seat share, and the number of parties in the governing cabinet, particularly following a major transition in government.
\end{abstract}

Keywords: agenda-setting, coalition politics, issue attention, political parties, policy accountability, policy change 
How do political parties influence the issues addressed by public policy? The general consensus is that parties affect a range of political outcomes. Yet, this research leaves how and why parties matter unclear. Renewed interest in parties by public policy research has shown the most common way of accounting for them in statistical models, the use of dummy variables to look for broad, party based differences in the dependent variable, leads to, at best, mixed results (e.g. Baumgartner et al. 2009; John et al. 2014). Indeed, the parties' literature itself is not immune to the shortcomings of overly rough measures (e.g. Hibbs 1977) to represent what are ultimately complex and dynamic actors (Strøm 1990). Furthermore, this approach cannot address the broad political context such as changing economic conditions or coalition governance structures.

We build on this research to argue that parties' influence on policies depends on attributes such as their ideology and ability to maintain cohesion and their strategic context (see Budge et al. 2010; Bevan and Greene 2016). As studies of economic voting and party strategy suggest (Whitten and Palmer 1999; Lewis-Beck and Stegmaier 2000; Hellwig 2012; Greene 2016a; Williams et al 2016), contextual factors such as the state of the economy have broad effects on parties' motivations to implement policy. We argue that the factors influencing parties' parliamentary capabilities and incentives for policy change have the greatest effect on the policy agenda ${ }^{\mathrm{i}}$ following a major transition in the partisan control of government. This focus allows us to isolate the effects of the governing context on parties when differences between governments are most likely to occur. We develop a series of hypotheses that consider the effect of the political context on parties' motivations and ability to influence policy based on studies of party election strategies and government behavior both following and in between partisan 
transitions in government. These hypotheses account for parties' incentives to change issues addressed by public policy and the constraints imposed by partisan and institutional context.

We focus our investigation on public policy, specifically, issue attention, where the exact effect of parties remains open for debate (Wlezien and Soroka 2010; Bevan and Greene 2016), despite the fundamental importance of agenda-setting in the policy-making process (Baumgartner and Jones 1993). Scholars demonstrate mixed evidence of partisan effects on individual issues or policies (e.g. healthcare - Tsebelis 2002; compliance with international treaties - Jensen and Spoon 2011) and government budgets (Wlezien and Soroka 2010), but have yet to explore parties' role in the broader distribution of issues addressed by government. Using data on primary legislation from six Comparative Agendas Project (CAP; www.comparativeagendas.net) countries, we consider how parties' traits and their context affect the stability of legislative agendas from a measure introduced by Mortensen et al. (2011). This measure aggregates differences in attention issue by issue through an overall index of stability in attention from year to year. ${ }^{\mathrm{ii}}$ We develop a new measure of partisan transition that accounts for whole sale change in government and more subtle changes in parties' coalition participation. We conduct analyses using time series cross-sectional methods aimed at pinpointing party influence from differences in party traits and contexts.

Understanding how and when the content of an agenda changes is at the heart of policymaking research. Our framework allows us to begin testing theories of policy change and democratic accountability that provides a more general approach than past case studies or single issue focused analyses. This approach builds on similar work focused on understanding aggregate patterns of issue attention through correlational and diversity based analyses (Baumgartner et al. 2009; Jennings et al. 2011; Boydstun et al. 2014). The results show that 
parties' influence on the policy agenda depends on government type, the government's general ability to influence legislation and the economy following a major transition in government. Collectively, we offer evidence that the incentives and constraints placed on the partisan content of governments influence the distribution of policies they pursue.

\section{Still Looking for the Party? Partisan Influence and Agenda Stability}

Scholars have long sought to link public policy and policy outcomes with parties' issue priorities and preferences. Despite substantial effort, research likely misses parties' influence when they rely on overly broad indicators for parties. Parties are diverse organizations that respond to changes in political context. As organizations, parties' priorities are likely more fluid than traditional accounts assume. We propose that parties' evolving characteristics and roles within the governing process lead to consistent partisan based policy revisions to the governing agenda. While the largest differences between parties emerge immediately following complete transitions in power, we also expect subtle intra-election differences.

Party leaders face competing incentives to achieve goals for winning elections and developing policy (Strøm 1990; Adams 1999; Spoon 2011). For example, parties' campaign messages reflect incentives for leaders to selectively emphasize issues, change the relative location of their preferences or present ambiguous policy statements (Adams et al. 2005; Meguid 2008; Somer-Topcu 2009; 2015; de Vries and Hobolt 2012; Schumacher et al. 2013; AbouChadi and Orlowski 2016). However, parties are often assumed to pursue strategic or selectively emphasized issues once they take office to avoid a reputation of acting unaccountably (Adams 1999; Carey 2009). Indeed, Jensen and Spoon (2011) show that governing parties' positions even influence policy compliance with international environmental agreements such as the Kyoto protocol. 
Economic conditions and public opinion provide broad indicators of parties' future success (Adams et al. 2009; Soroka and Wlezien 2010; Williams et al. 2016). Voters regularly punish or reward parties for economic performance (Lewis-Beck and Stegmaier 2000). Fearing voters' retribution, governing parties focus their attention to fixing a poor economy. Given voters' reliance on economic conditions as a shorthand for parties' competencies (Green and Jennings 2012a; 2012b), parties avoiding an appearance of incompetence will change their policy messages (Hellwig 2012; Greene 2016a; Williams et al. 2016) and presumably policy behavior (Bevan and Greene 2016) under a weak economy. Negative conditions clearly place strong incentives for governing parties to focus on fixing the economy. A government that does nothing to respond to these conditions will appear irresponsible and broadly incompetent, particularly when they have been in office for some time.

Our hypotheses distinguish years with a partisan transition, when a new party or set of parties take control of government, and years without a transition, where the same party or coalition maintains control. We focus our first hypothesis on the role of the economy when the same government remains in power contending that positive economic conditions free parties to diversify their agendas. A government with a growing economy will turn attention to alternate topics as voters are broadly content with the government's policies (Green and Jennings 2012a; 2012b). This discussion has implications for the issues that governments address based on the incentives the economy places on parties to appear accountable and competent. With a declining economy, agenda stability will increase as parties' change their attention from focusing on more diverse priorities to repairing the economy. Conversely, a growing economy is broadly requisite to focus on alternate policy priorities. As the rate of economic growth picks up steam governing parties expand their policy activities, decreasing agenda stability. ${ }^{\text {iii }}$ This argument follows from 
related findings on the effect of the government's economic focus on the ability to attend to other issues (Jennings et al. 2011) and is consistent with Green-Pedersen and Mortensen's (2010) finding that parties respond to economic conditions in office. Our first hypothesizes summaries this perspective.

H1a) A strong economy decreases agenda stability during non-transition years.

The economy strongly predicts partisan transitions cross-nationally (Lewis-Beck and Stegmaier 2000). Differences in ideological prescriptions for an ailing economy lead new governments to radically shift parliament's policy attention based on their proposed agenda. For example, a socialist party facing a poor economy might focus its prescriptions for slow growth on increasing the social safety net or wages (Hibbs 1977). A conservative government might instead focus on the efficiency of government operations or facilitating small business growth. This policy shift would only register the session immediately following a partisan transition; the new government would dedicate resources to its policy prescription until the economy improves. However, when partisan transitions occur during times of economic prosperity (Powell and Whitten 1993; Whitten and Palmer 1999; Hellwig 2012) incentives for a new government to change policy are far weaker. This logic leads us to hypothesize that partisan transitions in power moderate the effect of economic conditions.

H1b) A strong economy increases agenda stability following a partisan transition. 
Institutions and multi-party governance constrain parties' abilities to control policy. While procedural rules allow leaders to maintain parliamentary unity, parties' policy control depends on their need to build coalitions and internal cohesion (Huber and 1996; Döring 2001 and 2003; Tsebelis 2002; Bräuninger and Debus 2009). Although governing cabinets in parliaments rarely lose legislative votes (Huber 1996; Döring 2003), the observance of parliamentary discipline does not mean that parties' MPs hold cohesive preferences or have little influence on parliamentary acts. Indeed, MPs also have a range of tools to register their dissatisfaction with parliamentary leaders (Döring 2003; O’Brien and Shomer 2013). Parliamentary leaders with procedures at their disposal to maintain party unity (e.g. vote of confidence, the Guillotine, vote bloqué), should easily be able to maintain strong control over the parliament's voting behavior (Döring 2001, 2003; Bevan et al. 2011).

Despite high levels of observed discipline across the parliamentary world, intra-party politics influences parties' policy behavior. Forward looking MPs and intra-party factions know that parliamentary leaders have numerous tools to ensure a policy outcome. Intra-party groups, however, constrain leaders outside of the parliamentary arena by supporting intra-party leadership competitors (Ceron 2015; Greene and Haber 2016) or even switching to or forming a new party (O'Brien and Shomer 2013).

Therefore, the appearance of parliamentary discipline may mask serious disagreements over the relative location or issue priorities of a party. Policy agreements are often compromises debated privately between members of the same parliamentary group and individual MPs regularly work for individual interests and factions (Thomassen and Andeweg 2004; Budge et al. 2010). Governing party leaders with a large majority likely play intra-party factions and groups against each other to achieve their desired outcome (e.g. the problem of competing principals - 
Carey 2009). Governments with more dominant majorities can even allow public observation of intra-party disagreement without fear of losing important legislative votes. British back bench rebellions or the French vote bloqué allow MPs to distinguish their preferences from the leadership without causing parliamentary defeat (e.g. Huber 1996). However, parliamentary leaders with a small majority must ensure that no intra-party group abandons the party at a key moment. To keep intra-party groups from defecting, small parliamentary majorities require greater intra-party log rolls or policy bargains.

Theories of parliamentary discipline indicate a similar impact of majority size (Cox and McCubbins 1994; Cox 2000), but offer few predictions for the issues addressed by parliamentary votes. Parliamentary procedures allocate legislative powers to the prime minister (Cox 1987; Döring 2001; 2003). While legislative powers are strong, most procedures ultimately require parliamentary votes. Yet, few MPs would risk losing control of government over disagreements on a single act.

This logic leads us to hypothesize that larger majorities enable party leaders to maintain a more stable policy agenda. Parliamentary leaders with a large majority have a greater number of intra-governmental options to coordinate a majority of MPs for specific policies. These negotiations likely happen at the coalition or party level(s) and will not openly appear on votes in parliaments with strong discipline. Governments seek to maintain an image of unity and avoid public divisions (Ceron 2015; Greene and Haber 2016). Leaders can also use parliamentary procedures to limit divisions that might damage government parties' future electoral success (Cox 2000). Parties allow 'free votes', providing no direction on how MPs should vote, on legislation that they are divided on or that they consider unimportant. Smaller legislative majorities face greater risks from any individual member defecting (O'Brien and Shomer 2013). 
Therefore, we predict that a small parliamentary majority incentivizes party leaders to initiate greater $\log$ rolls across issues.

H2a) A government controlling a larger percentage of seats increases agenda stability during non-transition years.

Agenda stability can be caused by a government content to maintain the status quo or one incapable of altering it. Minority governments, for example, only pass policies with assistance from non-government parties. Like divided governments in presidential systems, minority governments cannot unilaterally revise the policy agenda (Laver 1999). The government must negotiate with other parties to legislate. While parties may work with ideologically close parties to negotiate policies (Huber 1996), a minority's ability to drastically change the agenda is limited. Their largest power is control of legislative procedures (often referred to as "negative agenda control") through a veto. From our perspective, governments with relatively few seats will primarily protect the status quo, increasing agenda stability. This logic implies a parabolic effect of seat shares. Governments with less than a majority of seats will experience greater stability or more difficulty changing laws that persists throughout their tenure in office (Laver 1999). This leads us to the following clarification of our second hypothesis (where we expect no differences for minority governments in transition or non-transition years).

H2b) A government controlling a smaller percentage of seats (less than a majority) increases agenda stability. 
Studies of parliamentary procedure emphasize timing (Huber 1996). The electoral cycle incentivizes parties to address issues at varying points between elections to appear accountable (e.g. Carey 2009). From this perspective, new governments prioritize electoral priorities and easy compromises before turning to more complicated policies (Greene 2016b). New governments following a partisan transition will seek to pass legislation consistent with their priorities. However, the extent that a new government can initiate reforms depends on its relative seat strength. Larger majorities require fewer negotiations to change policy, whereas governments with smaller delegations will be more at the mercy of individual MPs or factions. Governments with smaller delegations require greater time to initiate necessary policy bargains between groups to pass legislation, while governments with larger delegations can quickly change policy following a transition, reducing agenda stability. This logic leads us to hypothesize that a partisan transition moderates the effect of the size of the government's seat share on agenda stability.

H2c) A government with a larger percentage of seats decreases agenda stability following a partisan transition.

Multiparty coalitions also structure policymaking. Relative to single party majorities, coalition governance complicates and constrains partisan influence; parties negotiate policy outcomes both within their own parties and with coalition partners (Warwick 1994; Tsebelis 2002; Martin and Vanberg 2011). Parties unconstrained by coalition partners exert strong, positive control of parliament's voting behavior (Döring 2003). In this context, parties primarily 
face constraints imposed by the party's own ability to maintain unity in parliamentary votes. This leads to the following prediction;

H3a) Single party governments lead to less agenda stability than coalition governments.

However, multiparty coalitions also contain diverse interests. Coalitions with distinct partisan constituencies must enact policies to maintain each party's support. Cabinet positions linked to distinct issue jurisdictions structure coalition negotiations (Laver and Shepsle 1996). This implies that coalitions face greater challenges to altering the policy agenda. The number of coalition partners matters as well as how those parties prioritize issues (e.g. Bäck et al. 2011). Coalitions containing parties with a range of preferences must use logrolls across diverse issues to initiate policy change. Without compromises, coalitions end sooner than those capable of negotiating across issues (Warwick 1994; Greene 2016b). A greater number of parties increase the range of policy. Furthermore, from a principal-agent perspective, multiple parties enable the executive to treat parties as competing principals (Carey 2009). ${ }^{\text {iv }}$ From this viewpoint, the executive uses different intra-coalition groups to construct support for their most preferred legislation by offering policy changes on other issues as payment for the parties' support. This implies that across issues, the effect of negative agenda control dissolves when coalitions contain a greater number of parties.

H3b) Coalitions with more parties have a less stable agenda. 
The degree of partisan transition becomes complicated in parliaments featuring coalitions. For example, if a two party coalition forms following an election in which only one of the parties changes, previous research has struggled to identify a method to study such transitions. Following studies of portfolio allocation and government formation (Bäck et al. 2011), we add that changes in the relative cabinet seat share of parties indicates the coalition's originality. This implies that even if the same parties were included within a coalition following an election, changes in the relative percentage of seats each party contributes to the coalition influences the extent of the transition between coalitions. A major reversal in parties' fortunes changes the negotiated policies the government pursues. We theorize that transitions are not always dichotomous, but smaller shifts in coalition composition represent an important, but slighter transition than a wholesale change.

In summary, we hypothesize that parties' context and characteristics construct the policy agenda. Economic conditions construct governing parties' perceptions of future electoral success. Governments with a large percentage of seats quickly and easily adjust policy, whereas smaller majorities struggle to enact policies without substantial logrolls. Minority governments, incapable of altering the status quo, maintain a stable agenda. Single party governments are less stable than coalitions, but coalitions with more parties are less stable than those with fewer parties. Finally, transitions in governing parties lead to changes in the agenda; new parties shift the government's attention, but the degree of change depends on the extent of the partisan transition.

\section{Data and Methods}


To test our hypotheses on partisan influence we use data on primary legislation from parliaments in countries included in the Comparative Agendas Project (CAP). We focus analyses on Canada, Denmark, France, the Netherlands, Spain and the United Kingdom (UK); ${ }^{\mathrm{v}}$ multiparty systems in parliamentary democracies. Our cases range from majoritarian systems (UK) to more consensus based systems (Denmark). We use this data for the longest available period for each country from 1960 (to match our economic data) to $2008 .^{\text {vi }}$

We operationalize our dependent variable, agenda stability, ${ }^{\mathrm{vii}}$ using primary legislation from each country. Based on the CAP major topic coding system, we measure agenda stability as the difference in issue attention for each country across issues from year to year (Mortensen et. al. 2011). We use the following formula to calculate the dependent variable:

$$
A S_{t}=100-\left(\sum_{i=1}^{n}\left|\operatorname{Leg}_{t, i}-\operatorname{Leg}_{t-1, i}\right|\right) / 2
$$

Leg equals the percentage of primary legislation on an issue at time, $t$, and time, $t-1$, with the absolute value of the difference summed over all possible issues in the agenda $(n)$. This value is divided by 2; as the maximum value is equal to 200 and the minimum value is 0 and is subtracted from 100. Agenda stability $(A S)$ is highest at 100 and lowest at 0 . Therefore, our dependent variable accounts for how attention changes across the range of issues between years. For example, if a government distributes policies identically in year, $t$, and year, $t-1$, then the agenda stability measure equals 100 . However, if a government addresses a completely different set of issues in the second year, then our dependent variable equals 0 . The measure accounts for relative change in the percentage of laws on each topic between years, rather than the total number of laws allowing us to determine whether parties make major changes in the substantive distribution of policy. 
Figure 1 presents our agenda stability measure for the six countries.

[Figure 1 about here]

Figure 1 offers several insights into agenda-stability. In particular, constant agenda stability within and across countries is far from the norm. Policies generally change from year to year. The exception is Denmark in the early 1970s where a minority government exhibited perfect stability as it was unable to produce any legislation for a period of time. A comparison of the average level of agenda stability for majority governments of the UK and Spain to other countries also demonstrates that single party governments tend to have lower levels of agenda stability.

To test our hypotheses, we make use of an autoregressive distributed lag model of agenda stability. In particular, we conduct time series cross-sectional analyses with panel corrected standard errors of agenda stability. ${ }^{\text {viii }}$ We focus on pooled analyses because our hypotheses include general statements concerning coalitions, government transitions and parties that we expect to hold across the range of countries. The analyses include a lagged dependent variable (agenda stability $\mathrm{t}_{-1}$ ) to account for the autoregressive nature of agenda stability as evidenced by each series' autocorrelation and partial autocorrelation functions.

\section{Independent Variables}

Our first independent variable captures the state of the economy in each country using World Bank data. Specifically, we employ a measure of the percentage GDP growth to capture the country's level of economic prosperity. This approach avoids potential issues posed by economic measures often associated with specific parties, such as the relationship between rightwing parties and inflation (Hibbs 1977; Bevan and Greene 2016). We expect that poor GDP growth increases agenda-stability as parties focus on prescriptions for repairing the economy. 
Our second independent variable measures the strength of government control as the percentage of government seats. Data on government composition comes from the ParlGov dataset (Döring and Manow 2012). We include the percentage of seats for all members of a governing cabinet to address its relative parliamentary power. We predict that a smaller majority makes for a less stable government in the long run, unable to easily maintain a policy agenda as government leaders must induce MPs to support the party's proposals. We include the square term for government seats to account for the parabolic effect; we predict greater stability for large majorities and small minority governments, but less stable small majorities.

We further measure the effective number of coalition parties (ENCP) in the governing cabinet to account for inter-party coalition negotiations. ${ }^{\text {ix }}$ We assume that high ENCP, cabinets with more, equally sized parties, indicates a more complex and difficult to manage cabinet relative to single party governments. We hypothesize that ENCP lowers agenda stability.

To account for transitions in government control, we develop a continuous transition variable. Our indicator follows a similar logic to the agenda stability measure indicating the extent to which the governing cabinet changes during a transition. This measure was constructed using the following formula:

$$
\underset{\text { transition }_{t}}{\text { Cabinet }}=\left(\sum_{p=1}^{n} \mid \% \text { c seats }_{t, p}-\% \text { c seats }_{t-1, p} \mid\right) / 2
$$

In the cabinet transition formula, $\% c$ seats refers to the percentage of seats each party, $p$, contributes to the cabinet. We subtract the percentage seats from year, $t$, and, $t-1$, for each party and aggregate the absolute value of that change. ${ }^{\mathrm{x}} \mathrm{We}$ then divide the total number by two so that the scale ranges from zero to one. 
Our measure of transition therefore accounts for the amount of change in the distribution of parties in the governing cabinet from one year to the next. This allows for a partial transition when coalition partners change even between elections. In the case of a complete transition in partisan control such as the switch between the Tories and New Labour in the UK in 1997, the measure takes the maximum value of 1 . Alternate measures based on various thresholds for change in government composition coded 1 when the threshold was passed and 0 otherwise produced the same general inferences, but also produced poorer fitting models. ${ }^{x i}$ This operationalization allows us to measure cabinet similarity even when there has been no election or when there are only small changes in the distribution of cabinet seats following an election.

We further include interactions of our transition variable with our economic, majority size, and ENCP variables. A strong economy also leads to a unique effect with a party transition leading to a higher level of agenda stability; new governments hesitate to offer a radical shift in policy when the economy is doing well. Governments with a large majority are more capable of immediately implementing their program following a transition. ENCP has a similar, but independent effect on agenda stability. As ENCP increases stability becomes harder to maintain, particularly following a transition where key policies of all members of the coalition are pushed through to build a functional government.

\section{Analyses}

Table 1 lists the results of our pooled time series cross-sectional analyses for all six countries. We present models with and without interactions with our transition variable and with and without squared government seats.

[Table 1 about here] 
The results in Table 1 largely support our hypotheses across each of the three specifications. We focus our discussion on Model 3 as it represents the most complete specification. In particular, our first hypothesis predicts that positive economic conditions decrease agenda stability (H1a), but that the effect of the economy reverses during a transition (H1b). The coefficient for GDP growth rate is negative, but not statistically significant at conventional levels. However, the coefficient for economic conditions following a partisan transition is more informative. The positive and statistically significant coefficient for the interaction with Party Transition supports our prediction (H1b). When a party transition occurs under a strong economy the new government largely focuses on a similar policy agenda. Conversely, a poor economy leads new governments to drastically change the policy agenda.

We demonstrate this effect graphically in Figure 2. ${ }^{x i i}$ Strong economic growth leads new partisan governments to stable policy agendas following a transition. On the other hand, moderate or negative growth rates lead to greater instability. This finding supports a perspective in which new partisan governments address a weak or stagnant economy differently than the previous government.

[Figure 2 about here]

Our second set of hypotheses predict that majority governments controlling a larger percentage of seats have increased agenda stability because they control the legislative agenda (H2a), but that smaller minority governments will also have greater agenda stability because they struggle to change the policy agenda (H2b). Therefore, these hypotheses predict a parabolic relationship where approximately $50 \%$ government seats will be the least stable. We also predict that this relationship reverses for majority governments following a partisan transition (H2c). 
Table 1 provides evidence for support our second set of hypotheses on the percentage seats controlled by the governing cabinet. The coefficients for \% Government Seats and its squared term are in the expected directions. The negative coefficient for the $\%$ Government Seats is strong and negative, whereas its square is positive, indicating that the effect of the variable reverses. This effect is similar when interacted with Party Transition, although the magnitude of change increases.

We graph the predicted effect of the proportion seats when there is no transition and a complete transition in Figure 3. ${ }^{\text {xiii }}$ The graphical evidence indicates that minority governments have more stable agendas than majority governments both in transition and non-transition years, but that as majority governments gain more seats, this effect reverses. As we predicted the effect is parabolic ( $\mathrm{H} 2 \mathrm{a}$ and $\mathrm{H} 2 \mathrm{~b})$, although the predicted effects are not statistically different for majority governments because of the limited number of cases at the extremes. Furthermore, Figure 3 shows that in transition years, the effect of seat share actually leads to a more stable agenda than in non-transition years (counter to $\mathrm{H} 2 \mathrm{c}$ ), although the predicted effects are not quite statistically significant at conventional levels. Additional analyses presented in Table 1, excluding the transition interaction (Model 2), lead to stronger results in support of $\mathrm{H} 2 \mathrm{~b}$, but the results do not quite reach statistical significance for majority governments.

[Figure 3 about here]

While we find only limited support for hypotheses on government seat shares, there is clearer evidence that the number of parties in government changes agenda stability. Consistent with H3a, the coefficient for Single Party Governments lead to less stable agendas than multiparty governments, although the coefficient is only significant for transition years. 
Also in line with our predictions, ENCP is negative and significant when interacted with Party Transition. A coalition containing greater ENCP changes the agenda more than coalitions with fewer parties (H3b). Much like the impact of single party governments, the effect of ENCP is only statistically significant in transition years. We demonstrate this effect graphically in Figure 4. Coalitions where one party controls nearly all of the seats (converging on $E N C P=1$ ), are more stable than coalitions containing a larger number of parties. ${ }^{\text {xiv }}$ This evidence connects well with studies showing that coalitions initially deal with the easy compromises and then focus on protecting their accomplishments later on (Martin and Vanberg 2011; Greene 2016b).

[Figure 4 about here]

\section{Conclusion}

We argue that the constraints and incentives imposed on parties dictate issue attention in parliamentary governments. We find that parties often have large effects on the stability of government agendas. As studies of economic voting and party election strategy predict (Whitten and Palmer 1999; Hellwig 2012; Greene 2016a; Williams et al. 2016), this effect is not as simple as much of the analyses focused on party politics would suggest; government responsiveness to the economy, coalition size, and the number of coalition parties affect the ability to maintain a stable policy agenda. The results demonstrate their effect is greatest when there is some transition between the parties controlling the governing cabinet. Whereas previous studies failed to find much effect on specific policy outcomes, we show that the aggregate effect of partisan transitions depends on the factors that change parties' ability and incentives for altering the policy agenda. 
We find that the effect of party transitions on agenda stability come from a range of parliamentary governments. While we believe that these results are indicative of a broader trend across the democratic world, our sample limits our inferences about politics in contexts with weaker party discipline or greater numbers of institutionally designated veto players (e.g. the United States). However, we are confident that our perspective will travel well to alternate contexts, as many key theoretical concepts build on studies of government accountability and party politics in contexts with different institutional configurations (e.g. Carey 2009). Likewise, issue focused studies find evidence of partisan effects in various settings (e.g. Jensen and Spoon 2011).

Our results hold important implications for scholars of public policy, party government and our understanding of democratic politics. For those interested in studying a partisan effect, our results suggest that single party governments with small majorities facing strong economic growth are the most likely to radically shift policy during non-transition years. Furthermore, our theory suggests that intra-party factions play a meaningful role in policy-making. Our analysis complements evidence that the preferences of diverse groups of activists, MPs and party leaders often deviate at party congresses (Ceron 2015; Greene and Haber 2016) and in government (Huber 1996; Laver 1999; Carey 2009; Kam 2009). Intra-party variation in priorities, therefore, should also influence the distribution of parties' attention (Mortensen et al. 2011).

Public policy research has increasingly become interested in questions of partisan influence. While much research shows that parties' have only limited impacts on specific policy outcomes, this study suggests that the lack of evidence for a partisan effect may be an artifact of coding decisions. Our approach strips away assumptions about the exact differences in parties' policy priorities, but accounts for parties' and governments' broad characteristics. We show 
evidence of consistent change in the distribution of policy following partisan transitions and, importantly, between transitions as well. New partisans in government dedicate resources to build a different policy agenda than the preceding government. This effect is greatest when the resolve and ability to change policy is highest: under a weak economy and in single party governments. Unsurprisingly, once the transition is complete and a new government establishes an agenda, it becomes more stable.

Party politics research often focuses on detailed preferences and competitive situations, but it has only begun to extend these insights to government changes in issue attention. While the relative location of parties' preferences is important, the party's policy agenda and priorities are also important for political outcomes. Further research explaining when and why parties adopt policies in strategic contexts connects to research linking traditional issue competencies to behavior in office and bridge the divide between public policy and party politics research.

Finally, we add that these results indicate that parties offer real substantive differences once they enter office. Even small transitions lead to changes in the policy agenda. While voters may be unaware of parties' detailed policy goals, using simple heuristics such as party labels and economic conditions, our perspective suggests that citizens can form relatively sound expectations on parties' behaviors in office. 
Biographical note: Shaun Bevan is Lecturer in Quantitative Political Science at the University of Edinburgh. Zac Greene is a Chancellor's Fellow and Lecturer in Political Science at the University of Strathclyde.

Address for correspondence: Shaun Bevan, University of Edinburgh, Edinburgh, EH8 9LD, UK. email: shaun.bevan@gmail.com / Zac Greene, University of Strathclyde, Glasgow. G1 1XQ, UK. email: zacgreene@gmail.com.

\section{ACKNOWLEDGEMENTS}

We presented draft of this study at the September, 2014 Meeting of the Midwest Political Science Association in Chicago, IL, USA, and the 2014 Comparative Agendas Project conference in Konstanz, Germany. We are grateful for comments from Will Jennings of Southampton University and Ian Budge of the University of Essex. We would like to thank the editors and our anonymous reviewers for their insightful comments and support.

\section{NOTES}

\footnotetext{
${ }^{\mathrm{i}}$ We refer to the policy agenda as the distribution of issues addressed in parties' manifestos or government policy (Bevan et al. 2011). We refer to agenda-setting as the broad process of constraining which issues are attended to by government. This usage contrasts the more constraining definition used in studies of legislative behavior, which refers to the agenda as the structure and order of voting used to manipulate voting outcomes (Döring 2001).

${ }^{\text {ii }}$ We define issue attention as the distribution of policies passed in a year across issues.

iii Parties fear retribution for a weak economy. Governments appearing unconcerned with economic decline likely face even greater punishment (Green and Jennings 2012a; 2012b). A weak economy, therefore, leads to greater agenda stability because the government focuses policy attention on topics it believes improve the economy.

iv This perspective complements a veto players approach. While coalitions may contain multiple partisan agenda-setters (Tsebelis 2002), more parties increase the likelihood of ideologically
} 
'captured' parties, but not the total number of effective partisan veto players. More parties, however, increase the number of demands across issues and allow the prime minister multiple routes to achieve policy.

$v *$ CAP: www.comprativeagendas.net

*Canada: www.snsoroka.com/data.html.

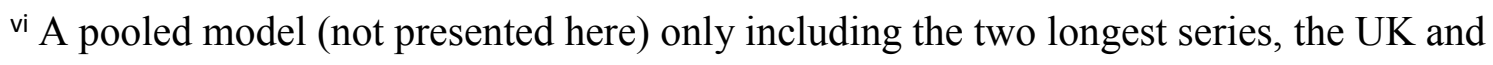
Denmark, produces the same inferences.

${ }^{\text {vii }}$ Our interest in agenda stability allows us to be neutral about the types of issues parties address to look for systematic change in the aggregate agenda. However, this work is related to research on diversity of that agenda and the tradeoff between issues using Shannon's H (Jennings et al. 2011; Boydstun et al. 2014; Greene 2016a). Nevertheless, the measures only weakly correlate (0.39).

${ }^{\text {viii }}$ As a robustness check the analyses were also run using a fractional logit model to account for agenda stability's bounding between 0 and 100 . These results produced the same inferences.

ix We use Shannon's H to construct ENCP. Our results are similar using a measure based on the Herfindahl index, although predictably t it does not perform as well as the Shannon's H. The coefficients are in the same direction, although they barely drop below standard levels of significance for the Herfindahl. The overall model fit decreases as indicated by the adjusted $\mathrm{R}$ squared.

${ }^{\mathrm{x}}$ In rare cases with multiple transitions in the same year, we use the value for the longest serving cabinet in that year.

${ }^{x i}$ Analyses of the effect of both pre- and post-election dummy variables as possible alternative measures led to poorer fitting models. 
xii We hold each of the primary independent variables at their mean values in Figure 2, varying GDP growth from its minimum to its maximum observed values for observations following transitions. 95\% Confidence Intervals are simulated from 1000 draws of the variance covariance matrix based on Model 3. The dashes across the bottom show the distribution of observations. This same approach is used for Figures 3 and 4.

xiii Wald tests of the coefficients' joint significance indicates that the effect of coalition size is statistically different from zero at the $95 \%$ level during transitions and $99 \%$ level during nontransition years.

${ }^{\text {xiv }}$ Models excluding the single party government variable with a parabolic ENCP variable lead to similar results. Both single party governments and coalitions with more parties have decreased stability relative to coalitions with only a small number of parties. 


\section{References}

Abou-Chadi, Tarik, and Matthias Orlowski (2016) "Moderate as Necessary: The Role of Electoral Competitiveness and Party Size in Explaining Parties' Policy Shifts.” The Journal of Politics Online Version.

Adams, J. (1999) Policy divergence in multicandidate probabilistic spatial voting. Public Choice, $103,103-22$.

Adams, J., Haupt, A., and Stoll, H. (2009) "What moves parties? The role of public opinion and global economic conditions in Western Europe." Comparative Political Studies 42 (5): 611-639.

Adams, J., Merrill, S., and Grofman, B. (2005) A Unified Theory of Party Competition. Cambridge: Cambridge University Press.

Bäck, H., Debus, M. and Dumont, P. (2011) "Who Gets What in Coalition Governments? Predictors of Portfolio Allocation in Parliamentary Democracies." European Journal of Political Research 50(4): 441-78.

Baumgartner, F. and Jones, B. (1993) Agendas and Instability in American Politics. Chicago: University of Chicago Press.

Baumgartner, F., Grossman, E. and Brouard, S. (2009) “Agenda-setting Dynamics in France: Revisiting the "Partisan Hypothesis." French Politics, 7, 2: 57-95.

Bevan, S., John, P. and Jennings, W. (2011) “Keeping Party Programmes on Track: The Transmission of the Policy Agendas of Executive Speeches to Legislative Outputs in the United Kingdom.” European Political Science Review 3(3): 395-417.

Bevan, S., and Greene, Z. (2016) "Looking for the party? The effects of partisan change on issue attention in UK Acts of Parliament." European Political Science Review 8(1): 49-72. 
Boydstun, A., Bevan, S. and Thomas III, H. (2014) “The Importance of Attention Diversity and How to Measure It." Policy Studies Journal, 42(2): 173-196.

Bräuninger, T. and Debus, M. (2009) "Legislative Agenda-Setting in Parliamentary Democracies.” European Journal of Political Research 48 (6): 804-839.

Budge, I., Ezrow, L., and McDonald, M. 2010 “Ideology, Party Factionalism and Policy Change: An Integrated Dynamic Theory." British Journal of Political Science 40(04): 781-804.

Carey, J. (2009) Legislative Voting and Accountability. Cambridge University Press.

Ceron, A. (2015) "Brave Rebels Stay Home: Assessing the Effect of Intra-Party Ideological Heterogeneity and Party Whip on Roll-Call Votes." Party Politics 21(2): 246-258

Cox, G. and McCubbins, M. (1994) Legislative Leviathan: Party Government in the House. Cambridge University Press.

Cox, G. (1987) The Efficient Secret: The Cabinet and the Development of Political Parties in Victorian England. Cambridge University Press.

Cox, G. (2000) “On the Effects of Legislative Rules.” Legislative Studies Quarterly 25 (2): 169192.

De Vries, C. and Hobolt, S. (2012) When Dimensions Collide: The Electoral Success of Issue Entrepreneurs. European Union Politics, 13, 246-268.

Döring, H. (2001) "Parliamentary agenda control and legislative outcomes in Western Europe." Legislative Studies Quarterly: 145-165.

Döring, H. (2003). "Party Discipline and Government Imposition of Restrictive Rules." the Journal of Legislative Studies 9, 4: 147- 163.

Döring, H. and Manow, P. (2012) Parliament and government composition database (ParlGov): An infrastructure for empirical information on parties, elections and governments in 
modern democracies. http://www.parlgov.org/static/static-2012/stable/download.html (accessed 15 October 2012).

Green, J. and Jennings, W. (2012a) "The Dynamics of Issue Competence and Vote for Parties In and Out of Power: An analysis of Valence in Britain, 1979-1997." European Journal of Political Research 51: 469-503.

Green, J. and Jennings, W. (2012b) "Valence as Macro-Competence: An Analysis of Mood in Party Competence Evaluations in Britain.” British Journal of Political Science 42:311343.

Greene, Z., and Haber, M. (2016) "Leadership Competition and Disagreement at Party National Congresses." British Journal of Political Science 46 (3): 611-632.

Greene, Z. (2016a) "Competing on the Issues How Experience in Government and Economic Conditions Influence the Scope of Parties' Policy Messages." Party Politics 22 (6): 809822.

Greene, Z. (2016b) "Working through the issues: how issue diversity and ideological disagreement influence coalition duration.” European Political Science Review FirstView: 1-25.

Green-Pedersen, C. and Mortensen, P. (2010) "Who Sets the Agenda and Who Responds to it in the Danish Parliament? A New Model of Issue Competition and Agenda-Setting." European Journal of Political Research 49 (2): 257-281.

Hellwig, T. (2012) “Constructing Accountability Party Position Taking and Economic Voting.” Comparative Political Studies 45(1): 91-118.

Hibbs, D.A., Jr. (1977) Political parties and macroeconomic policy, American Political Science Review 71: 1467-1487 
Huber, J. (1996) Rationalizing Parliament: Legislative Institutions and Party Politics in France. Cambridge University Press.

Jennings, W., Bevan, S. Timmermans, A., Breeman, G., Brouard, S., Chaques, L., GreenPedersen, C., John, P., Palau, A., and Mortensen, P. (2011) “Effects of the Core Functions of Government on the Diversity of Executive Agendas." Comparative Political Studies, 44(8): 1001-1030.

Jensen, C., and Spoon, J. (2011) “Testing the 'party matters' thesis: explaining progress towards Kyoto Protocol targets." Political Studies 59(1): 99-115.

John, P., Bevan, S., and Will Jennings (2014) "Party Politics and Policy Agendas: the case of the United Kingdom' in Christoffer Green-Pedersen and Stefaan Walgrave (eds.) AgendaSetting from a Policy Theory to a Theory of Politics. Chicago: Chicago University Press.

Kam, C. (2009) Party Discipline and Parliamentary Democracies. Cambridge University Press. Laver, M. (1999) “Divided Parties, Divided Government.” Legislative Studies Quarterly 24: 529.

Laver, M. and Shepsle, K. (1996) Making and breaking governments: Cabinets and legislatures in parliamentary democracies. Cambridge University Press.

Lewis-Beck, M. and Stegmaier, M. (2000) "Economic Determinates of Political Outcomes." Annual Review of Political Science 3: 183-219.

Martin, L., and Vanberg, G. (2011) Parliaments and Coalitions: The Role of Legislative Institutions in Multiparty Governance. Oxford University Press.

Meguid, B. (2008) Party competition between unequals: Strategies and electoral fortunes in Western Europe. Cambridge University Press Cambridge. 
Mortensen, P., Green-Pedersen, C., Breeman, G., Chaqués-Bonafont, L., Jennings, W. John, P., Palau, A., and Timmermans, A. (2011) "Comparing Government Agendas Executive Speeches in the Netherlands, United Kingdom, and Denmark." Comparative Political Studies, 44, 8: 973-1000.

O’Brien, D. and Shomer, Y. (2013) “A Cross-National Analysis of Party Switching.” Legislative Studies Quarterly 38(1): 111-41.

Powell, B. and Whitten, G. (1993) “A Cross-National Analysis of Economic Voting: Taking Account of the Political Context.” American Journal of Political Science 37, 2: 391-414.

Schumacher, G., de Vries, C. and Vis, B. (2013) "Why do Parties Change Position? Party Organization and Environmental Incentives.” Journal of Politics 75 (2): 464-477.

Somer-Topcu, Z. (2009) “Timely Decisions: The Effects of Past National Elections on Party Policy Change." Journal of Politics, 71: 238-48.

Somer-Topcu, Z. (2015) "Everything to Everyone: The Electoral Consequences of the BroadAppeal Strategy in Europe." American Journal of Political Science 59(4): 841-854.

Soroka, S. and Wlezien, C. (2010) Degrees of democracy: Politics, public opinion, and policy. Cambridge University Press.

Spoon, J. (2011) Political Survival of Small Parties in Europe. University of Michigan Press.

Strøm, K. (1990) Minority Government and Majority Rule. Cambridge: Cambridge University Press.

Thomassen, J. and Andeweg, R. (2004) “Beyond Collective Representation: Individual Members of Parliament and Interest Representation in the Netherlands." The Journal of Legislative Studies 10(4): 47-69. 
Tsebelis, G. (2002) Veto Players: How Political Institutions Work. Princeton: Princeton University Press.

Whitten, G. and Palmer, H. (1999) “Cross-National Analysis of Economic Voting." Electoral Studies 18: 49-67.

Williams, L., Seki, K., and Whitten, G. (2016) “You’ve Got Some Explaining To Do: The Influence of Economic Conditions and Spatial Competition on Party Strategy." Political Science and Research Methods 4 (1): 47-63. 
Table 1: Time Series Cross-Sectional Analyses of Agenda Stability

\begin{tabular}{|c|c|c|c|}
\hline & $\begin{array}{c}(1) \\
\text { Model } 1 \\
\end{array}$ & $\begin{array}{c}(2) \\
\text { Model } 2 \\
\end{array}$ & $\begin{array}{c}(3) \\
\text { Model } 3 \\
\end{array}$ \\
\hline GDP Growth Rate ${ }_{i t}$ & $\begin{array}{r}0.363^{+} \\
(0.193)\end{array}$ & $\begin{array}{l}-0.005 \\
(0.227)\end{array}$ & $\begin{array}{l}-0.031 \\
(0.231)\end{array}$ \\
\hline$\%$ Government Seats ${ }_{i t}$ & $\begin{array}{l}-9.481^{* *} \\
(2.897)\end{array}$ & $\begin{array}{l}-60.396^{* * *} \\
(17.421)\end{array}$ & $\begin{array}{l}-40.990^{+} \\
(21.879)\end{array}$ \\
\hline$\%$ Government Seats ${ }^{2}{ }_{\text {it }}$ & & $\begin{array}{l}48.557^{* *} \\
(16.915)\end{array}$ & $\begin{array}{c}31.467 \\
(21.048)\end{array}$ \\
\hline $\mathrm{ENCP}_{\text {it }}$ & $\begin{array}{l}-0.401 \\
(0.756)\end{array}$ & $\begin{array}{c}0.130 \\
(0.913)\end{array}$ & $\begin{array}{l}0.110 \\
(0.907)\end{array}$ \\
\hline Single Party Government ${ }_{i t}$ & $\begin{array}{l}-3.137^{*} \\
(1.266)\end{array}$ & $\begin{array}{l}-1.897 \\
(1.395)\end{array}$ & $\begin{array}{l}-2.042 \\
(1.386)\end{array}$ \\
\hline Party Transition $_{\text {it }}$ & $\begin{array}{l}-1.403 \\
(1.231)\end{array}$ & $\begin{array}{l}5.206 \\
(7.108)\end{array}$ & $\begin{array}{c}18.883^{+} \\
(11.000)\end{array}$ \\
\hline GDP Growth Rate $_{i t}$ X Party Transition ${ }_{i t}$ & & $\begin{array}{l}2.853^{* * *} \\
(0.717)\end{array}$ & $\begin{array}{c}2.931^{* * *} \\
(0.725)\end{array}$ \\
\hline $\mathrm{ENCP}_{\text {it }}$ X Party Transition ${ }_{\text {it }}$ & & $\begin{array}{l}-4.994^{+} \\
(3.025)\end{array}$ & $\begin{array}{l}-5.176^{+} \\
(3.058)\end{array}$ \\
\hline $\begin{array}{l}\text { Single Party Government }{ }_{\text {it }} \text { X Party } \\
\text { Transition }_{\text {it }}\end{array}$ & & $-10.548^{*}$ & $-10.979^{*}$ \\
\hline$\%$ Government Seats $_{\text {it }}$ X Party Transition ${ }_{\text {it }}$ & & $(5.148)$ & $\begin{array}{l}(5.243) \\
-48.667 \\
(34.211)\end{array}$ \\
\hline$\%$ Government Seats $^{2}{ }_{\text {it }}$ X Party Transition ${ }_{\text {it }}$ & & & $\begin{array}{c}41.598 \\
(35.557)\end{array}$ \\
\hline Lagged DV: Agenda Stability ${ }_{\mathrm{it}-1}$ & $\begin{array}{c}0.555^{* * *} \\
(0.059)\end{array}$ & $\begin{array}{l}0.557^{* * *} \\
(0.062)\end{array}$ & $\begin{array}{l}0.561^{* * *} \\
(0.063)\end{array}$ \\
\hline Constant & $\begin{array}{c}41.156^{* * *} \\
(5.648) \\
\end{array}$ & $\begin{array}{l}53.266^{* * *} \\
(7.776)\end{array}$ & $\begin{array}{c}47.816^{* * *} \\
(8.656)\end{array}$ \\
\hline$R^{2}$ & 0.434 & 0.495 & 0.499 \\
\hline Root Mean Squared Error & 6.236 & 5.949 & 5.957 \\
\hline Observations & 206 & 206 & 206 \\
\hline
\end{tabular}


Figure 1: Agenda Stability by Country Over Time

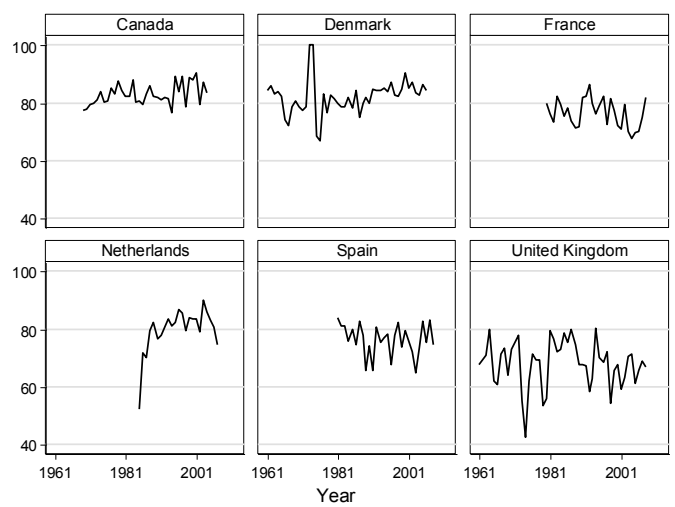

Figure 2. Effect of the Economy on Agenda Stability Following a Party Transition

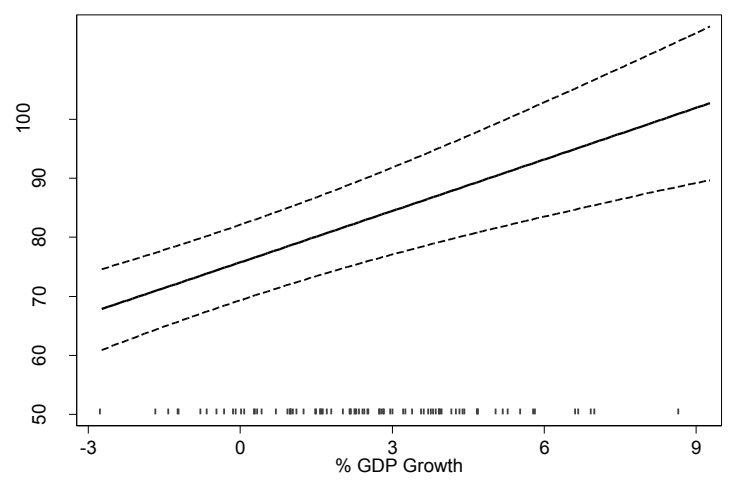

Figure 3. Effect of Coalition Seat Share on Agenda Stability
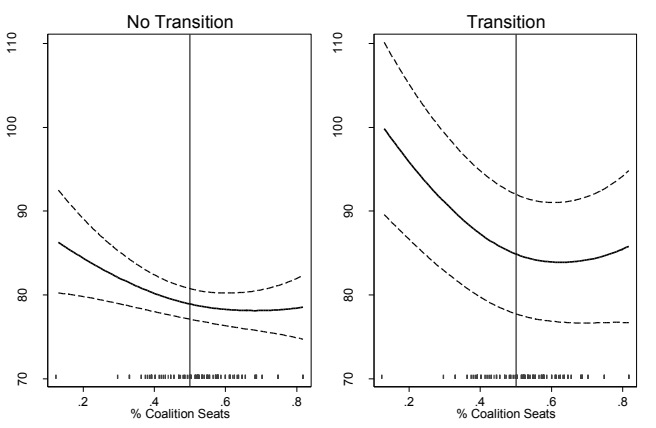

Figure 4. Effect of ENCP on Agenda Stability Following a Party Transition

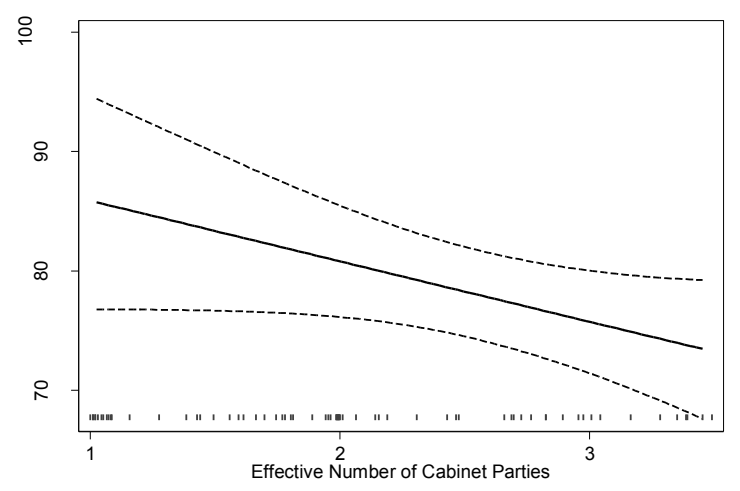

